Vol. 44, N. 2 : pp. $205-212$, June, 2001

ISSN 1516-8913 Printed in Brazil

\section{BRAZILIAN ARCHIVES OF BIOLOGY AND TECHNOLOGY}

AN INTERNATIONAL JOURNAL

\title{
Production of Flammulina velutipes on Coffee Husk and Coffee Spent-ground
}

\author{
Fan Leifa ${ }^{1}$, Ashok Pandey ${ }^{2}$ and Carlos R. Soccol ${ }^{1 *}$ \\ ${ }^{1}$ Laboratorio de Processos Biotecnologicos, Departamento de Engenharia Quimica, Universidade Federal do \\ Parana, CEP 81531-970, Curitiba - PR, Brazil; ${ }^{2}$ Biotechnology Division, Regional Research Laboratory, \\ Trivandrum-695 019, India
}

\begin{abstract}
Solid state cultivation (SSC) was carried out to evaluate the feasibility of using coffee husk and spent-ground as substrates for the production of edible mushroom Flammulina under different conditions of moisture and spawn rate. The strain of $F$. velutipes $L P B 01$ was adapted for a coffee husk extract medium. Best results were obtained with 25\% spawn rate, though there was not much difference when lower spawn rates (10-20\%) were used. Ideal moisture content for mycelial growth was $60 \%$ and $55 \%$ for coffee husk and spent-ground, respectively. With coffee husk as substrate, first fructification occurred after 25 days of inoculation and the biological efficiency reached about $56 \%$ with two flushes after 40 days. With spent-ground as substrate, first fructification occurred 21 days after inoculation and the biological efficiency reached about $78 \%$ in 40 days. There was decrease in the caffeine and tannins contents (10.2 and 20.4\%, respectively) in coffee husk after 40 days. In coffee spent-ground, the tannin contents decreased by $28 \%$ after 40 days. These decrease was attributed to the degradation of caffeine or tannins by the culture because these were not adsorbed in the fungal mycelia. Results showed the feasibility of using coffee husk and coffee spent-ground as substrate without any nutritional supplementation for cultivation of edible fungus in SSC. Spent ground appeared better than coffee husk.
\end{abstract}

Key words: Flammulina velutipes, coffee husk, coffee spent ground, solid state cultivation, fructification, biological efficiency

\section{INTRODUCTION}

Flammulina ranks at fourth place in the category of edible mushrooms for production and consumption. During 1990, its production was estimated to be approximately 143,000 tons, which increased to 230,000 tons in 1994, showing a remarkable jump of $61 \%$ (Chang 1996). According to Yang (1986) and Wang (1995), it's been first cultivated in China during the $8^{\text {th }}$ century. In 1928 , Moriki cultivated it with sawdust and rice bran in Japan (Nakamura, 1981). During the 1960s, its cultivation revolutionized in Japan, which became its largest producer in the world and enjoyed this position till the 1980s. Since the early 90's, China has occupied the first place in its production. It was estimated that in the Mainland China it was produced about 200,000 tons during 1995 (Meiging, 1997). Production data from different other countries too indicated a faster growth rate in terms of its total production. In the United States, for example, the production of Flammulina increased at an estimated rate of $25 \%$ or more per year for the last four years (Royse, 1995).

\footnotetext{
* Author for correspondence
} 
Production of Flammulina is based on synthetic substrate contained in polypropylene bottles or bags. The substrates most utilised are agricultural residues, such as corncobs, cottonseed husk, sugarcane bagasse, etc., besides sawdust (Chang, 1989; Yang, 1986; Fan et al, 1990; Wang, 1995; Royse, 1995).

Coffee husk and spent-ground are the two important agro-industrial residues in the coffee producing countries. According to International Coffee Organisation, there are more than 50 countries producing coffee (ICO, 1998). At different stages from harvesting to the processing and consumption, coffee husk and spent-ground are generated in more than two millions tons quantity yearly (Tango, 1971; Soccol, 1995, Pandey and Soccol, 2000). Brazil is the largest producer of coffee in the world and thus coffee residues too. In Brazil, the coffee cherries are generally processed by the dry method, resulting coffee husk, which is rich in organic nature and nutrients. It contains compounds such as caffeine, tannins, and polyphenols (Fan et al 1999a, 1999b). Coffee spent-ground, the residue, which is obtained during the processing of raw coffee powder to prepare 'instant coffee', is another residue obtained from coffee industry. This also contains caffeine, tannins and polyphenols, although in lesser quantity. Due to the presence of these compounds (caffeine, tannins and polyphenols), these organic solid residues show toxic nature and thus have not been utilised potentially. This has also led the problem of environmental pollution.

With the advent of biotechnology, attempts have increasingly been made globally to make potential use of agro-industrial residues for value addition by production of enzymes, organic acids, bioactive secondary metabolites, single-cell protein, etc. (Pandey et al. 1988, 1999a,b). Solid state fermentation (cultivation) has been often found promising in this regard (Pandey 1992a, 1994, Pandey et al. 2000, Pandey and Soccol 1998, Soccol 1996, Soccol and Krieger 1998). Several attempts have been made to use residues of coffee industries in Brazil for its biological detoxification and production of mushrooms, aroma compounds, etc. (Brand et al. 2000, Fan et al. 2000a,b, Soares et al. 2000). An attempt was made by Thielke (1989) to cultivate $F$. velutipes on coffee spentground. Song et al (1993) also reported the cultivation of $F$. velutipes on coffee spent-ground. However, there is no report on application of coffee husk as substrate for the cultivation of $\mathrm{F}$. velutipes.

The objective of this work was to use coffee husk and spent-ground for the cultivation of $F$. velutipes in solid culturing, which would primarily provide edible mushroom and simultaneously help in resolving their disposal problem which otherwise poses a serious environmental concern. The work involved adaptation of the strain of $F$. velutipes in coffee husk extract medium and to evaluate mycelial growth at different spawn rates and moisture contents and ability of fructification in the coffee husk and spent-ground as the substrates. The final substrates and fruit body were analysed to determine the contents of caffeine, tannins, protein and fibre in view of finding their possible utilisation after fermentation.

\section{MATERIALS AND METHODS}

Micro-organisms and growth medium: A strain of $F$. velutipes LPB 01 was used in the experiment. The strain was routinely maintained on PotatoDextrose-Agar (PDA) at $4^{\circ} \mathrm{C}$. The culture was adapted for a coffee husk extract medium as described earlier for other mushrooms (Fan et al. 2000a,b).

Spawn preparation: The sawdust of Eucalyptus sp. $(80 \%)$ and rice bran $(20 \%)$ was used for the spawn preparation. The mixture was adjusted at the moisture of $60 \%$ (Yang, 1986) and then filled in the glass jar of $500 \mathrm{ml}$ capacity. After autoclaving $\left(121^{\circ} \mathrm{C}\right.$, one $\left.\mathrm{h}\right)$, the spawn medium was inoculated with bits (one disc of one $\mathrm{cm}$ in diameter) of mycelia of strain growing vigorously in PDA slants and then incubated at $24^{\circ} \mathrm{C}$ in dark. The spawn in the jars was ready for inoculation to the substrate after 20 days growth when the mixture turned totally white.

Solid state cultivation (SSC): The raw coffee husk and spent-ground (sun dried) were obtained from the local factories. SSC was carried out using substrates filled in plastic bags of 20x35 cm size, by taking $100 \mathrm{~g}$ substrate in each bag on dry wt basis. These substrates were moistened with water (60\%) generally $4-5 \mathrm{~h}$ before autoclaving and were autoclaved at $121^{\circ} \mathrm{C}$ for $1.5 \mathrm{~h}$. When cooled, these were inoculated with the spawn (10\%) and mixed thoroughly to facilitate rapid and uniform mycelial 
growth. The mouth of bags was sealed using a cotton plug and thread. Then they were incubated in the dark at $24^{\circ} \mathrm{C}$. Mycelial development in the bag was observed and noted each day. Three bags were marked for collecting samples $(20 \mathrm{~g})$ each five days during 25 days for analysis of protein and fibre contents.

Effect of moisture and spawn rate: Substrates were prepared with different moisture such as 45 , $50,55,60,65$, and $70 \%$ for SSC. Similarly, different spawn rates were tested, which included $2,5,10,15,20$, and $25 \%$. After the 20 days fermentation, the protein and fibre contents in the substrate were measured.

Production of fruit body: The substrates were prepared as described above. Moisture and spawn rate were adopted according to the SSC. After 20 days, the jars were transferred to a lighted environmental chamber $(90 \%$ relative humidity, $20{ }^{\circ} \mathrm{C}$ ) to allow stimulation of air, humidity and light to facilitate fruiting body development. After the fructification of two flushes, the protein and fibre contents in the residues were measured.

Biological efficiency: Biological efficiency was determined as described previously (Fan et al. 2000a,b).

Analytical methods: The protein contents were determined by Kjeldahl method. The fibre contents were determined by taking $2 \mathrm{~g}$ substrate in $200 \mathrm{ml}$ $\mathrm{HCl}(1.25 \%)$ and boiling for 30 minutes. The whole contents were filtered and the solids were again boiled in $200 \mathrm{ml} \mathrm{NaOH} \mathrm{(1.25 \% )} \mathrm{for} 30$ minutes. After filtering, the solids were thoroughly washed first with distilled water, then with alcohol and ethyl acetate $(20 \mathrm{ml}$ each), respectively and dried at $60^{\circ} \mathrm{C}(\mathrm{AOAC}, 1975)$. The results reported are the average values of triplicate assays. Caffeine was determined using the modified method as described by the IAL (1985), using chloroform as solvent. For this, samples (2g) were mixed with $15-\mathrm{ml}$ conc. $\mathrm{H}_{2} \mathrm{SO}_{4}$ in $100-\mathrm{ml}$ glass beaker and heated in a boiling water-bath for $15 \mathrm{~min}$. The mixture was added to $50-\mathrm{ml}$ distilled hot water (boiling) and again heated for $15 \mathrm{~min}$ as above. The mixture was filtered using Whatman filter paper and the filtrate was neutralised using $\mathrm{NaOH}(1 \mathrm{~N})$. Caffeine was extracted from the neutral filtrate by treating with chloroform. All the organic fractions were pooled and the concentration of caffeine was determined in the pooled fraction by spectrophotometer $(276.5 \mathrm{~nm})$. Tannins were measured according to the method described in the manual by Ministerio de Agricultura (1986). For this, samples (5-g) were mixed with distilled water $(200-\mathrm{ml})$ and heated for 2-h. After filtering, 5-ml sample was mixed with equal amount of Folin-Denis reagent and saturated $\mathrm{Na}_{2} \mathrm{CO}_{3}$ (10-ml). The volume was made $100 \mathrm{ml}$ by adding distilled water. The concentration of tannins was determined in this by reading the absorbance at $760 \mathrm{~nm}$ in a spectrophotometer.

\section{RESULTS AND DISCUSSION}

\section{Adaptation of the strain}

The strain of $F$. velutipes LPB 01 grew well in coffee husk extract medium, showing 7.87 mm.day ${ }^{-1}$ mycelial growth and $45.8 \mathrm{mg}$ biomass.plate ${ }^{-1}$ in 10 days (data not shown). It indicated that coffee husk could be used as substrate by this fungus.

\section{SSC using coffee husk}

Figure 1a shows the content of protein and fibres in the fermenting coffee husk at different periods of time. As is evident, the protein content showed an increasing trend with the increase in cultivation period. The trend with fibre contents was same, though in reverse order, which decreased with the time of cultivation.

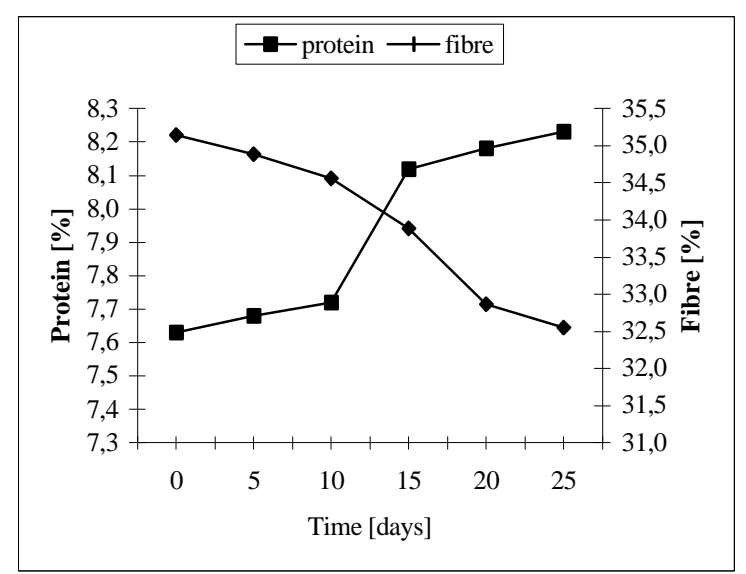

Figure 1a - Changes in protein and fibre contents in coffee husk during 25 days of SSC.

Figure $1 \mathrm{~b}$ shows the SSC of coffee husk at different moisture levels in the substrate during 25 days of growth. As is apparent, the substrate with 
$60 \%$ moisture resulted in maximum protein and minimum contents of fibres. The mycelial growth in this case was very vigorous (visual observation). At $45 \%$ substrate moisture, the growth as evidenced by protein content and visual observation was lowest. When the substrate moisture was $75 \%$, the fermentation was very poor and was almost comparable to that with $45 \%$. Moisture has been termed as a very crucial factor in solid culturing. It is reported that in SSC an optimum level of moisture is crucial a factor as high moisture level results in decreased substrate porosity, which in turn prevents oxygen transfer. At the same time low moisture level leads to poor accessibility of nutrients, resulting poor growth (Pandey 1992a,b).

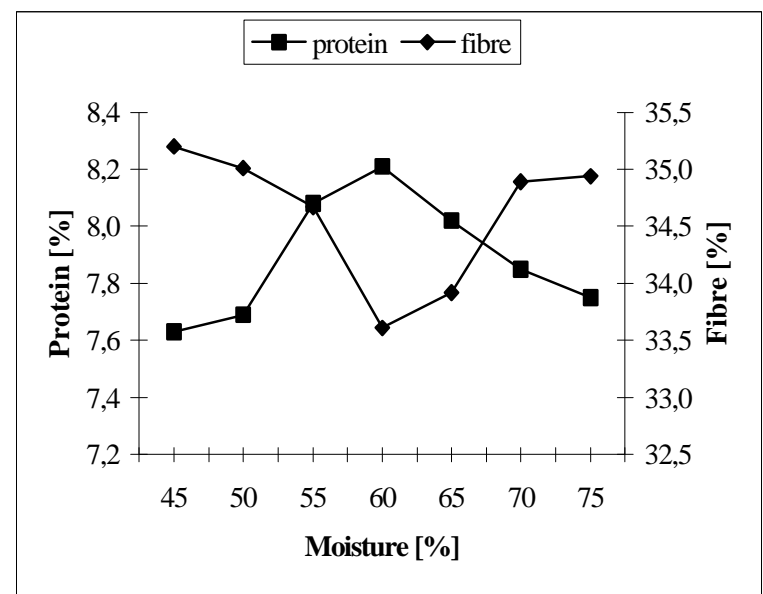

Figure 1b - Effect of moisture on SSC of coffee husk after 20 days of growth.

Figure 1c shows the effect of different spawn rate on protein and fibre contents of coffee husk after 20 days of SSC. With the increase of spawn rate, the mycelial growth was more rapid and active and was maximum with $25 \%$ spawn rate. However, there was not much difference in protein contents between $10-25 \%$ spawn rate, and the mycelial growth (visual observation) was also not augmenting correspondingly. Hence, a spawn rate of $10 \%$ was considered suitable. The spawn rate has also been considered one of the principal factors for edible fungus cultivation in SSC. There has been much variation in spawn rate with different substrate. Rajarathnam and Bano $(1987 a, b)$ reported that a spawn rate less than $10 \%$ facilitated the contamination and decreased the biological efficiency, and therefore, they recommended higher $(20 \%$ or more) spawn rate. However, a $2 \%$ spawn rate has been recommended by most other authors for mushroom production on different substrates (Yang, 1986; Fan and Ding, 1990 and Wang, 1995).



Figure 1c - Effect of spawn rate on SSC of coffee husk after 20 days of growth.

\section{SSC using coffee spent ground}

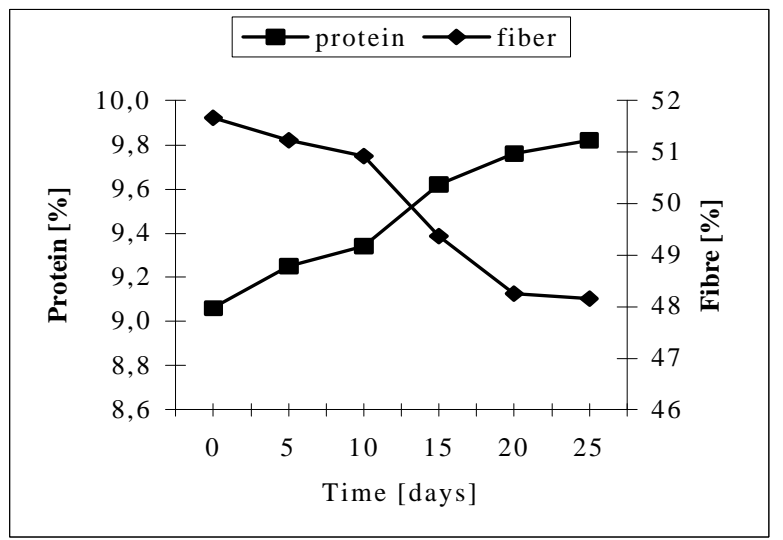

Figure 2a - Changes of protein and fibre contents during SSC of coffee spent ground in 25 days.



Figure 2b - Effect of moisture on SSC of coffee spent ground after 20 days growth. 
Figure 2a shows the SSF using coffee spentground as the substrate. It demonstrated that the protein content increased and fibres content decreased with the time of cultivation during 25 days. The ideal moisture for mycelial growth was $55 \%$, which resulted in maximum content of protein and lowest content of fibres in the substrate (Fig. 2b). It indicated that the variation of ideal moisture depended on the substrate. In this case, the 55\% moisture was appropriate for SSC.

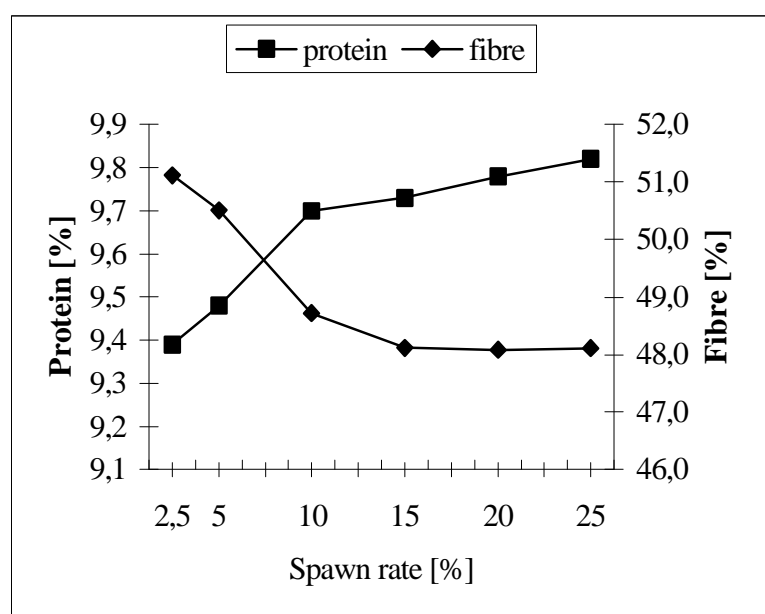

Figure 2c - Effect of spawn rate on SSC of coffee spent ground after 20 days growth.

In case of spawn rate, although $25 \%$ spawn rate resulted in highest content of protein and lowest content of fibres in the substrate, there was not much difference in their contents with $10 \%$ spawn rate (Fig. 2c). Thus, from economics point of view we recommended $10 \%$ spawn rate as appropriate.

\section{Fructification on the coffee husk and spent- ground}

When coffee husk was used as the substrate, the primodia appeared after 25 days of inoculation; the biological efficiency reached at about $56 \%$ with two flushes in 40 days. There is no report on the production of Flammulina using coffee husk. Thus, our findings are very important. With spent ground as substrate, first primodia of fructification occurred 21 days after inoculation and the biological efficiency reached about $78 \%$ with two flushes in 40 days. Thielke (1989) who first reported the fructification of $F$. velutipes supplemented the medium with yeast extract while Song et al. (1993) who also obtained the fruit body from spent-ground, supplemented it with corn flour. In the present studies, we did not provide any nutrients or supplemented the medium with any other ingredients.

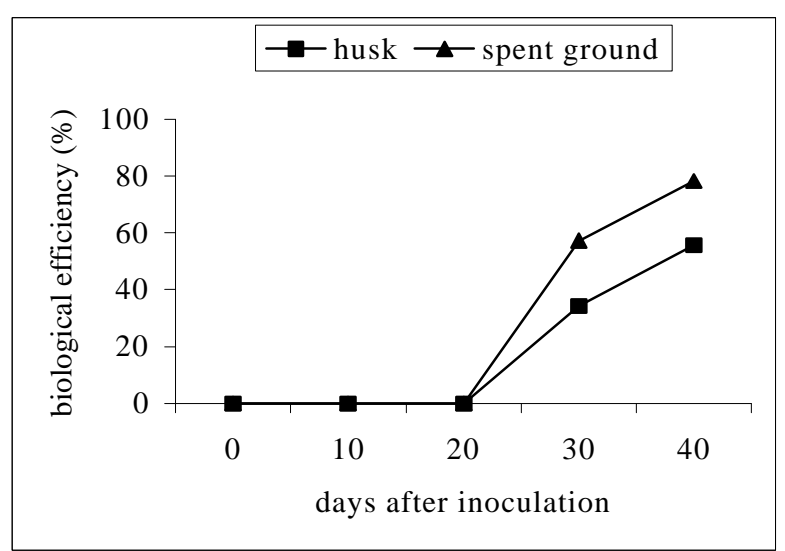

Figure 3 - Biological efficiency of $F$. velutipes LPB 01 on the coffee husk and spent ground.

Figure 3 shows the biological efficiency of $F$. velutipes LPB 01 on coffee husk and spentground.

\section{Change of protein and fibre in the substrates before and after fructification}

Table 1 shows the initial and final contents of protein and fibres in the substrates. Although the mushroom body containing higher content of protein than the substrate took out majority of protein in the substrate, the content of protein in the substrate increased because of consuming relatively a lot of carbohydrates. The content of fibre increased in the final residue of coffee husk, being $10.70 \%$ while it decreased in the coffee spent ground after fructification $(-7.25 \%)$. The increase rate of protein was between 24.68 and $27.05 \%$. These modifications of protein and fibre contents in the substrates could be attributed to the weight loss during SSC, degradation of lignocellulose and liberation of $\mathrm{CO}_{2}$. It indicated that Flammulina has capability to degrading the lignocellulosic residues.

Table 1 - The contents of protein and fibre in the substrate before and after fructification of $F$. velutipes LPB 01

\begin{tabular}{ccccc}
\hline Parameters & \multicolumn{2}{c}{ Coffee husk } & \multicolumn{2}{c}{ Spent-ground } \\
\hline & protein & Fibre & protein & fibre \\
\hline Initial & 8.14 & 34.11 & 8.06 & 49.24 \\
Final & 10.15 & 37.76 & 10.24 & 45.67 \\
Increase or & +24.68 & +10.70 & +27.05 & -7.25 \\
decrease(\%) & & & & \\
\hline
\end{tabular}


Content of caffeine and tannins in the fruit body, initial and final coffee residues

Table 2 shows the contents of caffeine and tannins in the fruit body of Flammulina and coffee residues. The fruit body of Flammulina did not contain caffeine and tannins when grown on coffee husk or spent-ground. The contents of caffeine and tannins were decreased at 10.2 and $20.4 \%$, respectively in the fermented husk, which indicated that the fungal strain was able to degrade it partially. In spent-ground there was no caffeine detected after fermentation. This probably was due to its low initial concentration, which could have been degraded completely, but tannins concentration decreased by $28 \%$. There is no literature report about action of Flammulina on caffeine and tannins.

Table 2 - Contents of caffeine and tannins in the fruit body and final substrates after fructification of $F$. velutipes $\mathrm{LPB} 01$.

\begin{tabular}{ccccc}
\hline Parameters & \multicolumn{2}{c}{ Coffee husk $(\%)$} & \multicolumn{2}{c}{ Spent ground $(\%)$} \\
\hline & caffeine & tannins & caffeine & tannins \\
\hline Fruit body & 0 & 0 & 0 & 0 \\
Initial & 0.65 & 3.65 & 0.05 & 0.25 \\
Final & 0.58 & 2.91 & 0 & 0.18 \\
Increase or & -10.21 & -20.37 & -- & -28.00 \\
decrease & & & & \\
\hline
\end{tabular}

Due to the presence of these anti-physiological and anti-nutritional factors, coffee husk is not considered an adequate material as feed for cattle and other livestock, or substrate for bioconversion processes. Consequently, most of the husk remains unutilised or poorly utilised. If these toxic constituents could be removed, or at least degraded to a reasonably low level, it would open new avenues in their utilisation as feed. It will also improve its value to be used as substrate for bioprocesses (Fan et al. 2000a,b). Attempts have been made to degrade caffeine present in coffee pulp (which is generated by wet-processing of coffee cherries) and use it for the production of enzymes etc (Roussos et al., 1995; Hakil et al., 1998; Hakil et al 2000).

\section{CONCLUSIONS}

The studies showed the feasibility of using coffee husk and spent-ground without any nutrients supplementation for cultivation of $F$. velutipes LPB 01 in solid state cultures. Coffee spentground could be a more suitable substrate for its cultivation. There is no report on the production of Flammulina using coffee husk. Thus, our findings are very important. SSC offers a potential way to utilize these residues economically.

\section{ACKNOWLEDGEMENTS}

Financial assistance from the European Union (grant no INCO DC: IC18*CT 970185) and PNP \& D/CAFÉ-Coordinator EMBRAPA, Brazil (Projeto no 07.1.99.057) is gratefully acknowledged. C. R. Soccol would like to thank the CNPq for a scholarship under the Scientific Productivity scheme.

\section{RESUMO}

Cultivo no estado sólido foi utilizado para avaliar as possibilidades de utilizar a casca e a borra de café como substrato para a produção do cogumelo comestível do gênero Flamulina. A cepa de $F$. velutipes $\mathrm{LPB}$ foi adaptada em um meio contendo extrato de casca de café. Os melhores resultados em termos de produção do cogumelo foram obtidos com taxas de inoculação de $25 \%$, embora não tenha sido observadas diferenças significativas quando taxas inferiores foram utilizadas (10-20\%). $\mathrm{O}$ teor de umidade ideal para o crescimento micelial foi de $60 \%$ e $55 \%$ para a produção com casca e a borra de café.

Utilizando a casca de café como substrato, a primeira frutificação ocorreu após 25 dias de inoculação e a eficiência biológica foi de aproximadamente $56 \%$ com duas colheitas após 40 dias. Utilizando-se a borra de café como substrato, a primeira frutificação ocorreu 21 dias após a inoculação e a eficiência biológica alcançada foi de $78 \%$ em 40 dias de cultivo. Houve uma redução nos teores de cafeína e taninos da ordem de 10,2 e $20,4 \%$, respectivamente na casca de café após 40 dias. Na borra de café, os índices de taninos foram reduzidos em $28 \%$ após 40 dias. Esta redução foi atribuída à degradação da cafeína e taninos pela cultura. Os resultados mostraram a praticabilidade de usar a casca e a borra de café como substrato sem nenhum suplemento nutritivo para o cultivo sólido desse fungo comestível. A borra apresentou melhores resultados do que a casca de café. 


\section{REFERENCES}

Association of Official Analytical Chemists (1975), Official Methods of Analysis, 20 Edn., W. Horwitz (ed.), Washington

Brand, D.; Pandey, A.; Roussos, S. and Soccol, C. R. (2000), Biological detoxification of coffee husk by filamentous fungi using a solid state fermentation system, Enzyme Microb Technol., 27, 127-133

Chang, S. T. (1996), Mushroom research and development - equality and mutual benefit. Mush. Biol. Mush. Prod. 2, 1-10

Chang, S. T. (1989), Edible mushroom and their cultivation, CRC Press, Inc., Florida

Fan, L. F. and Ding, C. K (1990), Handbook of Mushroom Cultivation, Jiangxi Science and Technology Publishing House, Jiangxi, PR China

Fan, L.; Pandey, A. and Soccol, C. R. (1999a), Cultivation of Pleurotus $s p$. on coffee residues Proc. $3^{\text {rd }}$ International conference on Mushroom Biology and Mushroom Products and AMGA's $26^{\text {th }}$ National Mushroom Industry Conference October 12-16, Sidney, 301-310

Fan, L.; Pandey, A. and Soccol, C. R. (1999b), Cultivation of Lentinus edodes on the coffee industry residues and fruiting body production Proc. $3^{\text {rd }}$ International conference on Mushroom Biology and Mushroom Products and AMGA's 26 ${ }^{\text {th }}$ National Mushroom Industry Conference October 12-16, Sidney, 293-300

Fan, L.; Pandey, A. and Soccol, C. R. (2000a), Solid state culturing- an efficient technique to utilize toxic agro-industrial residues, J. Basic Microbiol., 40(3), 177-187

Fan, L.; Pandey, A.; Mohan, R. and Soccol, C. R. (2000b), Comparison of coffee industry residues for production of Pleurotus ostreatus in solid state fermentation, Acta Biotechnol., 20 (1), 41-52

Hakil, M.; Denis, S.; Viniegra-Gonzalez, G. and Augur, C. (1998), Degradation and product analysis of caffeine and related dimethylxanthines by filamentous fungi Enzyme Micro. Technol., 22, 355359

Hakil, M.; Viosinet, F.; Viniegra_Gonzalez, G. and Augur, C. (1999), Caffeine degradation in solid fermentation by Aspergillus tamarii: Effects of additional nitrogen sources, Process Biochem., 35, 103-109

Instituto Adolfo Lutz (IAL) (1985), Metodos quimicos e fisicos para analise de alimentos Normas analiticas de Instituto Adolfo Lutz 3rd, São Paulo, IMESP, 189-192, 195-196

International Coffee Organization- ICO (1998), Total production of exporting members. http://www.ico.org/proddoc.htm

Meiying, G. (1997), The selection and breeding of new strains of Flammulina velutipes in China Acta Edulis Fungi, 4(1), 8-14
Ministerio da Agricultura (1986), Secretaria nacional de defesa agropecuaria-laboratorio de referencia vegetal Metodologia de analise de bebidas e vinagres.

Nakamura, K. (1981), Mushroom cultivation in Japan, Asaki Publication House, Japan.

Pandey, A. (1992a), Recent process developments in solid state fermentation, Process Biochem., 27, 109116

Pandey, A. (1992b), Production of starch saccharifying enzyme in solid cultures. Starch/Starke, 39, 75-77

Pandey, A. (1994), Solid state fermentation- an overview. In- Solid State Fermentation, A. Pandey (ed.), Wiley Eastern Publishers, New Delhi, 3-10

Pandey, A. and Soccol, C. R. (1998), Bioconversion of biomass: A case study of ligno-cellulosics bioconversions in solid state fermentation. Brazilian Arch. Biol. Technol., 41(4), 379-390

Pandey, A. and Soccol, C. R. (2000), Economic utilization of crop residues for value addition - A futuristic approach, J. Sci. Ind. Res., 59(1), 12-22

Pandey, A.; Nigam, P. and Vogel, M. (1988), Simultaneous saccharification and protein enrichment fermentation of sugar beet pulp. Biotechnol. Letts., 10(1), 67-72

Pandey, A.; Soccol, C. R.; Nigam, P.; Soccol, V. T.; Vandenberghe, L. P. S. and Mohan, R. (1999a), Biotechnological potential of agro-industrial residues: II Cassava bagasse. Biores. Technol., 74, 81-87

Pandey, A.; Soccol, C. R.; Nigam, P. and Soccol, V. T. (1999b), Biotechnological potential of agro-industrial residues: I Sugarcane bagasse. Biores. Technol., 74, 69-80

Pandey, A.; Soccol, C. R. and Mitchell, D. (2000), New developments in solid state fermentation: I bioprocesses and products. Process Biochem., 35, 1153-1169

Rajarathnam, S. and Bano, Zakia (1987a) Pleurotus mushrooms. Part I A: Morphology, life cycle, taxonomy, breeding and cultivation, CRC Critical Reviews in Food Science and Nutrition, 26, 157-223

Rajarathnam, S. and Bano, Zakia (1987b), Pleurotus mushrooms. Part I A: Morphology, life cycle, taxonomy, breeding and cultivation, CRC Critical Reviews in Food Science and Nutrition, 26, 157-223

Roussos, S.; Aquiáhuatl, M. A.; Trejo-Hernández, M. R.; Perraud-Gaime, I., Favela, E.; Ramakrishna, M.; Raimbault, M. and Viniegra-González, G. (1995), Biotechnological management of coffee pulp: Isolation, screening, characterization, selection of caffeine-degrading fungi and natural microflora present in coffee pulp and husk. Appl. Microbiol. Biotechnol. 42, 756-762

Royse, D. J. (1995), Specialty mushrooms: cultivation on synthetic substrate in the USA and Japan. Interdisciplin. Sci. Rev. 20, 1-10

Soares, M.; Christen, P.; Pandey, A. and Soccol, C. R. (2000), Fruity flavour production by Ceratocystis fimbriata grown on coffee husk in solid state fermentation. Process Biochem., 35(8), 857-861 
Song, C. H.; Lee, C. H. and Huh T. L. (1993), Development of substrates for the production of basidiocarps of Flammulina velutipes. Korean J. Mycol., 21, 212-216

Soccol, C. R. (1995), Aplicações da fermentação no estado sólido na valorização de resíduos agroindustriais, França-Flash Agricultura, 4, 3-4

Soccol, C. R. (1996), Biotechnology products from cassava root by solid state fermentation. J. Sci. Ind. Res., 55, 358-364

Soccol, C. R. and Krieger, N. (1998), Brazilian experiment on valorisation of agro-industrial residues in solid state fermentation. In- Advances in Biotechnology. A. Pandey (ed.), Educational Publishers, New Delhi, 25-36
Tango, J. S. (1971), Utilização industrial do café e dos seus subprodutos Boletim do Instituto de Tecnologia de Alimentos-ITAL São Paulo, Brasil. 28, 49-73

Thielke, C. (1989), Cultivation of edible fungi on coffee grounds, Mushroom Science, 12, 337-343

Wang, N. L. (1995), Edible Fungi Cyclopedia of China, Agriculture Printing House, Beijing, PR China

Yang, X. M. (1986), Cultivation of Edible Mushroom in China, Agriculture Printing House, Beijing, PR China, 489-510

Received: September 08, 2000; Revised: December 20, 2000; Accepted: March 08, 2001. 